\title{
4 \\ Historical lessons about contemporary social welfare: Chinese puzzles and global challenges
}

\author{
R. Bin Wong
}

\section{Explaining China's past to find approaches to our common future}

We look out at the world around us and see problems and possibilities created by our social practices. We have some basic ideas about where conditions are better and where they are worse, on the basis of which our thinking about development seeks to create the traits found in good conditions elsewhere. The history that typically matters to Development Studies is of two kinds. There is the implicit distillation from certain European experiences, a set of related political, social and economic changes that collectively define modern conditions, a heady brew to be sure but I will suggest in this chapter it remains inadequately nourishing for our appetites to construct better futures. Alternatively, history's other lessons involve failures elsewhere, oft explained by either the limitations of the natives or the less worthy intentions of external actors conceived variously as benefactors and oppressors. We completely miss another kind of potential historical lesson, one that explains a non-western case through its continued reworking of earlier practices and priorities. When these efforts address large issues we deem of more general importance, understanding the historical lesson can matter not merely for a particular case but for our understanding of global issues more generally.

This chapter considers issues of social welfare and political accountability. It argues, contrary to the general implications of research and scholarly observations, levels of social welfare need not always vary positively with levels of democratic practice. I suggest instead that technologies of rule that enable concerns for social welfare can exist quite independently of European-derived ideas and institutions of political representation and government administration. Could these non-European practices suggest ways to approach social welfare challenges beyond the specific case of China, which is the main subject of this 
chapter? If so, our textbook understanding about social welfare challenges in the contemporary world may want to include some new historical lessons.

China's durability as a territorial unit is frequently noted by both specialists and in more general discussions, but it is more often assumed and taken as a natural fact than it is taken as a condition to be explained. Since no other imperial state in world history has bequeathed to its successors in the twenty-first century a government that continues to rule most all the territory and a far vaster population than was once ruled by an empire, China's reproduction of agrarian empire has to be considered a major subject in world history. This chapter takes on only a small part of this subject that connects quite directly to the capacities and commitments of the contemporary Chinese state toward its subjects. In particular, this chapter suggests how political accountability in both the eighteenth century and in contemporary China is achieved through balancing central-local relationships in ways that facilitate spatial integration through attention to equity issues. This is not to say that Chinese governments have consistently satisfied social welfare concerns; far from it. But the state's successes have been intimately tied to such satisfactions. These successes have had relatively little to do with democratic practices, at least as conventionally conceived, and for this reason offer a different perspective on thinking about how social welfare issues might be addressed in what continues to be a quite undemocratic world.

\section{Social spending and democracy: contexts for variation}

The proposition that democracies will spend more on social welfare than despotic regimes makes intuitive sense. If democracies make policies according to the will of the people, they will certainly favour public needs more than a despotic regime will since the latter seeks to maximize the despot's interests and welfare over those of his subjects. The economist Peter Lindert, for example, documents a relationship between democracy and social spending in his twovolume study Growing Public (Lindert 2004), which begins in the late nineteenth century among countries that have varying amounts of political representation. In an example perhaps more familiar to those engaged in development studies, Amartya Sen has famously contrasted Chinese and Indian efforts at famine relief to support the proposition that famines are less likely to take place the more democratic the regime. In brief, he observes 'that no major famine has ever taken place in any country with a multiparty democracy with regular elections and with a reasonably free press' (Sen 2002: 287). The finding holds across rich and poor democracies and is further supported by contrasts between China and India. China 'managed to have perhaps the largest famine in recorded history, during 1959-1962, in which 23-30 million people died, while the mistaken public policies were not revised for three years through the famine. In India, on the other hand, despite its bungling ways, large famines stopped abruptly with independence in 1947 and the installing of a multiparty democracy (the last such 
famine, “the great Bengal famine,” had occurred in 1943)' (Sen 2002: 287). The basic proposition appears to be a causal one - democracies do not have famines - and the logic is a political one. Rulers who need to be re-elected and who are subject to a free press cannot hide disasters and cannot afford to address them because people will not vote to continue them in power should they fail to address famine issues. The logic is a reasonable and general application of interest-based actions by government and citizens faced with a major social crisis like famine that people believe the government can intervene to prevent.

Innocent of Chinese history, the China-India contrast makes persuasive sense. If, however, we consider the existence in eighteenth-century China of complex large-scale famine relief campaigns and the storage of tons upon tons of grain for relief of seasonal food supply shortfalls, it becomes less clear that the degree of democratic accountability can explain government interventions to meet social welfare needs. The contrast of eighteenth-century conditions in China with those in the late 1950s demands some explanation that doesn't depend on levels of democratic accountability since such concepts seem ill-conceived to apply to China's past. To deal with these challenges we need to consider a bit of Chinese history.

\section{A brief lesson in Chinese history}

In the eighteenth-century Qing Empire, we find a well-ordered society in which the state spends considerable sums on water control, on food supply storage, and major famine relief campaigns. The state also stressed education; from time to time officials in different provinces made special efforts to establish schools to educate poorer boys who could not afford private school or tutors to prepare them for the studies needed to take the civil service examinations. Officials in some parts of the Empire also worked with local elites to establish orphanages and arrange for support of indigent widows. Social spending in eighteenthcentury China was often substantial. Just water control works alone likely averaged some 3.5 million taels annually in the mid-eighteenth century; in these same years bureaucratic salaries totaled some 6 million taels annually and the routine costs for the military about 18 million taels annually (Zhou 2002: 24-9). ${ }^{1}$ Water control expenditures thus ran to nearly 20 percent of the amounts spent on military maintenance and over half the amount budgeted for official salaries.

Chinese officials understood that the maritime regions of the Empire posed different opportunities and challenges than the landlocked interior. The eighteenth-century state had little need for revenues from maritime trade and was far more interested in controlling the European merchant presence on Chinese soil; interior regions presented varied social and natural environments that officials sought to stabilize culturally and develop economically (Wong 2004). The state, moreover, showed special awareness of the needs of more 
peripheral and poorer regions to which it sent resources in efforts to make the agrarian economy more viable for populations that were in some places growing quickly because of migration (Wong 1997: 105-39, Wong 1999: 210-45). Ideas about promoting food supply security and the importance of a materially secure population to the political fortunes of rulers go back to pre-imperial Chinese political thought and took various institutional forms over the two thousand years in which imperial rule was the norm more often than not. Ideas about promoting market-based economic growth and the state playing a considerable role in peripheral regions inspired a variety of polices in the last millennium of imperial rule, including the eleventh-century policies of Wang Anshi to develop state monopolies to management of merchant-led growth in the eighteenth century (Smith 1991, Millward 1998). Finally, a stress on the welfare of rural residents took on growing visibility after the fourteenth century as the proportion of people living in urban settlements appears to have declined; social stability reached far beyond the city walls within which most European notions of public order were conceived.

It would be convenient to attribute Chinese policy-making simply to a culturally specific political ideology that developed over many centuries. But political rhetoric alone seems inadequate to explain the differences between China and Europe regarding social spending before the advent of democracies. Henry IV in sixteenth-century France is reputed to have promised a chicken for every pot and eighteenth-century Frederick the Great in Prussia professed a concern for human welfare at the same time as he spent most of his time and energy, as well as his subjects' resources, on war-making. Our awareness of limited efficacy of welfare rhetoric in European cases prepared, at least indirectly, an earlier generation of scholars studying Chinese history to be skeptical of the practical relevance of political claims to paternal benevolence.

With the opening of Qing dynasty archives in the 1980s, scholars have gained a more empirically grounded understanding of state activities, including those related to social welfare (Will and Wong 1991). What we continue to struggle with is an explanation of the choices the Qing state made to embark upon such major programs. Some have suggested that as a conquering people from beyond the Great Wall, the Manchus, felt a particular need to legitimate themselves politically in terms of a long-standing rhetorical vision of good governance. This factor may explain some of the motivation, though it also seems that late seventeenth- and eighteenth-century emperors were tutored in texts and internalized a set of Confucian political beliefs that made their efforts more than the anxious instrumental acts of leaders who saw themselves as foreign and thus in special need of acceptance by those they ruled. Part of the explanation no doubt lies in the greater importance of warfare and military spending to early modern European rulers than late imperial Chinese emperors.

In the two centuries before Lindert's late eighteenth-century baseline for observing a rise in social spending first in England and then on the nineteenth- 
century European continent, social spending was more likely to be shouldered by local governments, if by governments at all. Charity by religious institutions formed a highly visible part of welfare efforts. For their parts, centralizing governments were busier with state-building which meant raising monies to build bureaucracies and armies (Tilly 1975, 1992). European state-makers competed with each other for territory and taxable populations, seeking to improve their geopolitical strength at the expense of other states. In contrast, the Chinese Empire was not part of a set of similar competing states. While the agrarian empire faced various semi-nomadic groups who could cause difficulties along shifting frontiers, the general pattern in earlier centuries had been for northern tribes to depend on a unified Chinese Empire to be a richer and more dependable source of goods than a weak and fragmented empire could possibly be. Nomads had, in other words, an interest in negotiating favorable terms for exchange and gift-giving with a strong rather than a weak agrarian empire.

The Chinese state was only overthrown once between the late fourteenth and early twentieth centuries and in that case the conqueror not only established control over all of the previous dynasty's territories, but also extended the Empire's northern and western territories. Under these general conditions, the need for military expenditures did not, indeed could not, fuel the growth of the Chinese state in the manner taking place in Europe. To the contrary, the Chinese state already had a civil service bureaucracy with a broad strategy of rule, which included social spending. The political logic of maintaining a stable agrarian empire called for ensuring the material security of the peasant population. The eighteenth-century Chinese state translated this general commitment into policies for opening new arable land, maintaining water ways and irrigation works, and spreading agricultural and handicraft technologies from economic cores to peripheries. One of the more expensive operations they mounted required massive efforts to build and maintain a system of civilian grain reserves and in times of extreme deprivation they made extraordinary efforts at famine relief (Will 1990, Will and Wong 1991).

Famine relief issues were enmeshed in broader concerns about state intervention to stabilize social conditions across an agrarian empire. The eighteenthcentury state provided what we would call today collective goods - peace, security, and economic infrastructure. Major projects required special efforts to mobilize monies and manpower; these campaigns made it possible to make major repairs and even improvements in water control management. The government's development of a granary system to store hundreds of thousands of tons of grain for sale and loan to needy people also depended on major campaigns. Since these campaigns were intermittent, people felt little need or desire to create clear principles for negotiating with officials over how much they owed in money or labour service. They tried whenever possible to evade or deflect the state's demands, a practice far easier than attempting to develop formal and explicit rules to govern negotiations. The routine presence of the late imperial 
state was limited - not surprising since its bureaucracy ruled a vast agrarian empire - and in the eighteenth century its extraordinary interventions could be positive, like famine relief, as well as negative, like financing a military campaign.

It should be clear that the demands of sustaining an agrarian empire are different from those of facing competing state-makers in Europe. Since the sizes of the physical spaces and populations are roughly comparable, we could imagine that the lessons to be drawn from these separate historical experiences might also be broadly comparable. The European lessons inform much of our basic understanding of modern state formation and economic development. The Chinese experiences to date have not been interpreted in a manner encouraging any lessons to be drawn. Knowing that this is not the place to offer a well-developed explication of the arguments and evidence for the Chinese state strategies and the general implications of their successes, it may still be a time when the possibility of Chinese lessons can at least be posed.

Given the very real limitations of administrative capacities in a pre-industrial political context, a state's abilities to rule bureaucratically over a large territory and population depended on encouraging positive relations between centre and locale. No political centre could command the coercive resources to impose constantly its will on its subjects. To be successful, a state had instead to offer some persuasive vision of good rule and implement policies that at least some of the time came close to achieving stated intentions. Local welfare needs figured prominently in the agenda for local social order expressed in Confucian political ideology and implemented through institutions designed to promote such a social order. The political success of agrarian empire depended on meeting the social welfare expectations of vast numbers of local communities. Social welfare and political viability were intimately connected, both in the rhetoric of the actors themselves and in the social practices we can observe and analyze. Since these practices emerge with neither the ideas nor institutions of democratic political regimes, we have identified a context separate from the conventionally expected ones for social welfare concerns proving fundamental to the successes of a political system achieving social order across large spaces and populations.

The eighteenth-century Chinese case suggests the hypothesis of effective rule being more likely to emerge across a large area when central governments more effectively meet local concerns for social welfare and economic prosperity. The plausibility of this possibility has been easy to ignore since we know that the principles were not in fact observed in some subsequent periods of Chinese history. Before considering further the possible general implications of Chinese historical practices for contemporary challenges more generally, some presentation of later Chinese situations in which the eighteenth-century logic of political success is absent is needed. 


\section{Nineteenth-century sorrows and twentieth-century tragedies}

In nineteenth-century China, taxation begins to increase dramatically at midcentury and bureaucratic effort is shifted from social spending to military and defense matters. The relative amounts of Chinese government expenditures devoted to social spending go down as military-related expenditures increase from the eighteenth through the nineteenth centuries, while the opposite trend occurs in Europe. The initial military threats and subsequent diplomatic resolutions with European powers begun in the late 1830s were followed by massive mid-century rebellions, and subsequent continuing institutional innovations in response to western challenges. The previous priority placed on social welfare expenditures was no longer possible, the central government's influence over local conditions increasingly limited. The central government was in fact successful in mobilizing ever larger revenues; it learned how to use western principles and practices of bank borrowing and public debt. But these kinds of successes were not accompanied by a continued capacity to fulfill the agenda for rule articulated and implemented in the previous century. While these limitations were not themselves directly responsible for the collapse of the dynasty - foreign pressures and the stresses created by them were far more important - formulating principles of rule after 1911 would include concern for local social order, even when no central government ruling the territory of the Qing dynasty was able to establish itself until 1949.

In the era of warlords that followed the dynasty's fall, as well as the decade of Nationalist rule and subsequent years of Japanese invasion and civil war with the Communists, there was no central government seeking to sustain social order through the maintenance of local welfare standards. Political instability and military turmoil reduced the country to a far more chaotic condition than could have even been imagined in the eighteenth century. China couldn't use the principles and practices of social welfare provision to create political order until a military security had been once again achieved. Such an outcome was by no means a foregone conclusion. There could have been a mix of successor states more similar to those that followed other cases of agrarian empire across Eurasia. That China in 1949 was once again a unified country, the government of which claimed sovereignty over most all of what had been the eighteenth-century Qing Empire's greatest extent, did however mean that the challenges of ruling local societies from a distant center once again entered onto the government's political agenda.

The Communist state reintroduced a form of centralized rule many of whose features would have been familiar to a mid-eighteenth-century ruler or his officials. The central state asserted its sole authority over issues of taxation, removing from lower levels of government any statutory opportunities to raise revenues. The central government claimed to control authority over personnel decisions throughout the country and implemented a set of principles for selecting and placing its officials, different in substance to be sure from late 
imperial principles, but similar in its assumptions about how the centre chose its officials according to a mix of political and bureaucratic criteria. Most relevant to the particular theme of this chapter, the central government embraced its responsibility for securing and hopefully improving the economic conditions of peasants and workers across the country. The first several years of Communist rule can be seen as the successful restoration of economic stability and social order in a country wracked by hyperinflation and starvation. Basic to these successes was arming local areas with the means to create social order with some minimal subsistence security. These achievements were not however secure because the new ideology demanded social change and aspired to economic development in ways unimaginable two hundred years earlier and most importantly, the state created tools of persuasion and coercion far exceeding those available in earlier eras.

From the government's zealous pursuit of what Mao Zedong called 'continuous revolution', the countryside was collectivized and increased output was expected from popular responses to government exhortations for ever greater efforts. Looking into these conditions helps us address what otherwise appears as historically implausible - a Chinese state of the late 1950s far less able to intervene in famine conditions than its mid-eighteenth-century predecessor was. Innocent of the particulars, it is difficult to imagine that a mid-twentieth-century authoritarian state with a far larger bureaucracy committed to major interventions in local social and economic life could prove less able than a mideighteenth-century state limited by pre-industrial technologies to ameliorate famine conditions.

Two contrasts in particular help us to begin to resolve the surprise. First, the mid-eighteenth-century Chinese central government received monthly grain price reports and harvest results or projections from every province of the empire. While harvest data were no doubt most always impressionistic and of uncertain quality, price data were usually quite reliable in this period. Provincial officials forwarded to the centre monthly summaries based on the high and low prices of each grain on local markets in each county, averaging some forty-odd per province, delivered to them every ten days. With such information, central government officials were in a surprisingly good position compared with others in the eighteenth-century world to anticipate harvest shortfalls and rising prices across a space as large as Europe for a population larger than many European countries put together. In comparison, officials in the late 1950s were expected to report ever-growing output from the formation of communes which concentrated many production and consumption decisions across many natural villages. False information about grain harvests obstructed the abilities of leaders to learn just how bad conditions became in many areas. Second, mid-eighteenth-century China had a well-developed commercial system in which long-distance movements of grain were a major activity. When poor harvests struck one area, grain movements adjusted according to market conditions. When market-based 
movements proved inadequate, officials could themselves travel to large grain markets and arrange purchases and transport of grain to their jurisdictions with great need. They would not do so, however, without first making use of the grain they stored in official granaries intended to ameliorate seasonal fluctuations in grain prices with spring sales and autumn purchases after new harvests brought down prices. In contrast China in the late 1950s had suffered a major dismantling of the earlier commercial networks so that there was no economic system through which price signals could influence flows of grain or to which officials could appeal for help in relieving supply shortages from areas with better harvests.

Changes in economic organization and administrative capacities matter more to explaining this Chinese contrast than do differences in democratic ideology and institutions. Similarly, the dramatically open response top Chinese officials have made to the spring 2008 earthquakes in Sichuan results from a desire to mobilize both domestic and foreign support in relief efforts and a desire to be seen as responsive to popular suffering. The US of course remains far more a democracy than China despite its hurricane relief efforts falling far short of what the Chinese have mounted for its earthquakes. Thus, it would seem the relationship between degree of democracy and responsiveness of government to social disaster is conditioned by other factors quite independent of democratic impulses.

Theories about public choice predicated on democratic forms of decisionmaking cannot help us explain the eighteenth-century Qing's levels of social spending. Nor can a narrow focus on political ideologies get us very far in explaining why Qing state social spending was higher in absolute and proportional terms than in European states of the same era since European rulers also made strong statements about the importance of their subjects' welfare. Finally, such theories cannot help explain the contrasts between Chinese conditions in the mid-eighteenth and mid-twentieth centuries. Economic institutions and administrative capacities seem useful for the temporal contrast within China, but how might we contrast the general approach to social spending to China today with other parts of the world? Does history matter, and if so how?

The social sciences approach issues of public finance and social spending in a variety of ways. Economists seek ways to make voter choice about governmentprovided goods and services approach in logic their consumer choices for private goods on the market, but the intrinsic differences between voting and market purchases make possible various alternative mechanisms for deciding upon how social spending normatively should take place. Political scientists and sociologists are more likely to address some combination of organizational and network features of decision-making on social spending to make clear how political connections matter and how organized interest groups make their voices heard. Much of what we learn is about institutional settings in advanced industrial societies and we do so through a set of principles embodying both normative 
values and analytical understandings. When Chinese study these foreign cases they focus on what they can consider the technical or scientific features of public finance and social spending so that the possibilities of borrowing from these advanced experiences and fitting them within a Chinese context becomes more plausible.

But how can they or we understand the formation and relevance of these Chinese contexts? The argument for how history matters centres on the role of earlier state practices for constructing and sustaining such a large territory under a centralized bureaucratic regime and the proposition that the strategies and preferences that animated those earlier practices can still matter today, even amidst conditions that both we and the Chinese perceive in fundamentally different terms discursively. For example, observers of China's reform-era changes have sometimes marveled at the open willingness of the government to tolerate diverse experimentation as it changes its institutional rules. Some China specialists have offered functionalist explanations of why such flexibility has been demanded by the circumstances for the reforms to succeed, but this begs the question of why the Chinese succeeded at being flexible when so many others do not approach institutional change with such an open and flexible manner. One set of reasons for this flexibility, I suggest, has to do with the naturalized quality of experimentation that comes out of earlier recognition of variation in the manner in which local order was sustained and extended. For instance, certain local institutions, including granaries and schools, were intended to be created and maintained by local elites who shared the Confucian political and social ideology of officials; the actual roles of elites and officials varied across China with officials playing a larger role where elites were less common, less wealthy and less willing. These variations were very much accepted in the eighteenth century. In the 1920s and 1930s, innovations and successes at promoting social order at the local level, most notably the conservative Confucian reformer Liang Shuming's efforts in Shandong province, could become models that central government officials wished to spread more widely, in ways not so dissimilar from how the Communist party state in the 1960s attempted to promote 'learning from Dazhai' as a model of self-reliance in a poor agricultural region. In a similar vein, the late imperial state had for centuries promoted a very general agenda of orthodox cultural practices regarding weddings and funerals and ancestor worship, while allowing tremendous variety of local deities to be worshipped as people desired, typically intervening only in rare instances when officials feared that some sect might threaten political stability. There is, in other words, a basis in history for permitting great variation in local social and political practices that form the unstated context for the ways in which economic reform experimentation has taken place.

Where a long history of fiscal administration exists, as is the case in China, the ways in which taxation policies change is enmeshed in the transformation of existing practices with innovations and changes working only in so far as they 
solve their targeted challenges without exacerbating difficulties in meeting some other set of concerns. A good example of this is the chronic underfunding of local government, a phenomenon made more severe since the mid-1990s, even in those areas where local government social spending had increased in the previous decade. During the 1980s and into the 1990s, those locales where township and village enterprises (TVE) blossomed, which included many of the areas with previously vibrant commercial economies before 1949, indeed typically for centuries, relied on revenues from these TVE as a source to fund local education, health and housing. As the central government initiated a series of tax reforms to reverse its slipping grasp over taxes as a percentage of gross domestic product (GDP) and as a share of total tax revenue (lower levels of government were increasing their relative shares), local governments previously able to engage in considerable social spending faced growing constraints. There were also local governments where TVE had not become a significant economic driver of growth and they continued to lack the ability to make many social expenditures.

In counties lacking much TVE, local officials levied additional taxes and fees upon agricultural households who could ill afford to bear these burdens. Readily available systematic data is scarce but Bernstein and Lü present figures from a Chinese study published in 1998 suggesting that peasant tax burdens were inversely related to income, suggesting what was in effect a regressive taxation regime (Bernstein and Lü 2008: 99). The problems with local levies in rural areas after the mid-1990s led to a phased reduction in agricultural taxes as well as turning miscellaneous fees into explicit taxes. Together the processes culminated in the end to agricultural taxation in 2006. This change is most significant symbolically because it marks the end of reliance on agriculture as a source of fiscal support, which agriculture had been for much of the two thousand years of imperial era history as well as for many political authorities in the twentieth century, including the People's Republic in its first several years of rule. In material terms, the end to agricultural taxation reflects the economic changes taking place in Chinese society - an urbanizing and industrializing society has a new fiscal base. The ways in which different levels of the state tap new sources of wealth began with local governments with TVE having the capacity for increased social spending followed by central government efforts to capture a greater portion of new sources of revenue. Relations among levels of government regarding the levying and sharing of fiscal revenues will no doubt prove dynamic and changing. Crucial among the challenges of the reform era for those areas that are neither urbanizing nor industrializing is how to develop a viable fiscal base for social spending.

The problem is obviously economic at its base - greater absolute poverty compared with places that are urbanizing and industrializing. But it can also be considered as part of a larger political issue, as do Bernstein and Lü, who stress the importance of local people having a say in the taxes that are levied upon them 
(Bernstein and Lü 2003, 2008). The essay appears in a volume, Taxation and StateBuilding in Developing Countries: Capacity and Consent (Brautigam et al. 2008), which develops the theme of consent of the governed to taxes as a key way to build democratic governance. Amidst poverty, however, some resource transfers have to be attempted if poverty is to be alleviated and social goods and services provided. The problems within China that result from such a situation provide a partial parallel to those that emerge for smaller countries that are poor and rural where foreign aid is a critical source of potential help that often gets used ineffectively and inappropriately. It is possible that officials in poor regions of China are prone to rent-seeking as there are fewer ways to amass wealth than there are in more dynamic economic areas.

The difference between the international and Chinese cases is that the latter, I argue at least in part for reasons with a long historical background, is committed to these transfers and as they are 'national' in scope, the forms of social identity and perceived interests and concerns will be far different than those between donor countries and the developing world. But what makes these transfers possible has little to do with democracy or even with consent in any explicit, consciously formulated manner. Historically, Chinese were drawn to make decisions favouring public expenditures because these helped to maintain peace and prosperity across their empire. Their situation contrasted sharply with early modern European rulers whose public expenditures went to war-making. Chinese governments began to take social expenditures seriously at an earlier date than they did and thus they present from a European perspective something of a puzzle, which we can solve once we move outside a frame of reference in which European experiences supply the norms. For their part, European states no longer compete militarily with each other, and we can even see some resource flows related to economic welfare issues across those states that belong to the European Union; while these will never resemble closely what takes place in China because the ideological and institutional bases of governance in China and Europe will long remain different, it changes our view of how social spending generally and transfers specifically develop when we introduce historical perspectives beyond those supplied by Europe.

\section{Conclusion}

Whatever the prospects and problems of fiscal transfers to fund social spending generally, what we see in China is a persistent concern by the central government to promote economic development and social services across both regional divides and urban-rural divides, each of which is a preference and concern we can see in earlier centuries. The differences in today's conditions, however, transform the nature of the challenges. Regarding regional disparities, it was a far easier task to imagine diffusing best technologies before the original Industrial Revolution and the subsequent changes that have transformed 
economic possibilities several times in the past two centuries. For urban-rural divides, eighteenth-century Chinese government officials managed to mitigate those gaps by promoting social spending across both rural and urban areas; much of their public goods investment went to water control, grain storage, roads and communications that benefited both urban and rural residents. Today the challenge is to extend the higher rates of social spending in cities to rural areas near them. This effort seeks to lessen part of the legacy of the institutionalized divide between urban and rural China for the first three decades of the People's Republic, a divide that helped China escape the massive problems of overpopulation and underemployment in many Third World cities before the past three decades of economic growth makes it easier to ponder how urban advantages, many of them associated with higher levels of social spending, can be extended to the countryside. The Chinese state takes a far more activist role in addressing what it considers the challenges of regional disparities and urbanrural gaps than we would anticipate in other parts of the world. One could argue that they must do so because their rapid growth rates make the challenges more salient than they would be were the economic transformation taking place at a slower rate. Yet, it does seem that urban-rural gaps remain pronounced in many parts of the developing world without the level of effort devoted to them that we see in China. If these impressions can be substantiated more fully, a case for a variety of ways in which history matters to explaining patterns of social spending as a feature of a larger set of issues about political accountability within and beyond democracies seems well worth making across the world generally.

\section{References}

Bernstein, Thomas and Xiaobo Lū (2003). Taxation without Representation in Contemporary Rural China, Cambridge: Cambridge University Press

Bernstein, Thomas and Xiaobo Lū (2008). 'Taxation and coercion in rural China', in Deborah Brautigam, Odd-Helge Fjeldstad and Mick Moore (eds) Taxation and StateBuilding in Developing Countries: Capacity and Consent, New York: Cambridge University Press, pp. 89-113

Brautigam, Deborah, Odd-Helge Fjeldstad and Mick Moore (eds) (2008). Taxation and StateBuilding in Developing Countries: Capacity and Consent, New York: Cambridge University Press

Millward, James (1998). Beyond the Pass: Economy, Ethnicity and Empire in Qing Central Asia, 1759-1864, Stanford, CA: Stanford University Press

Lindert, Peter (2004). Growing Public: Social Spending and Economic Growth Since the Eighteenth Century, Vol. 1, New York: Cambridge University Press

Sen, Amartya (2002). Rationality and Freedom, Cambridge, MA: Harvard University Press

Smith, Paul (1991). Taxing Heaven's Storehouse: Horses, Bureaucrats, and the Destruction of the Sichuan Tea Industry, 1074-1224, Cambridge, MA: Harvard University Press

Tilly, Charles (ed.) (1975). The Formation of National States in Western Europe, Princeton, NJ: Princeton University Press

Tilly, Charles (1992). Coercion, Capital and European States:AD 990-1992. Malden, MA: Blackwell

Will, Pierre-Étienne (Elborg Forster, trans.) (1990). Bureaucracy and Famine in Eighteenth-Century China, Stanford, CA: Stanford University Press 
Will, Pierre-Étienne and R. Bin Wong (1991). Nourish the People:The State Civilian Granary System in China, 1650-1850, Ann Arbor, MI: University of Michigan Center for Chinese Studies

Wong, R. Bin (1997). China Transformed: Historical Change and the Limits of European Experience, Ithaca, NY: Cornell University Press

Wong, R. Bin (1999). 'The political economy of agrarian China and its modern legacy', in Timothy Brook and Gregory Blue (eds) China and Capitalism: Geneologies of Sinological Knowledge, Cambridge: Cambridge University Press, pp. 210-45

Wong, R. Bin (2004). 'Relationships between the political economies of maritime and agrarian China, 1750-1850', in Wang Gungwu and Ng Chin-Keong (eds) Maritime China in Transition, 1750-1850, Wiesbadan: Harrassowitz Verlag, pp. 19-31

Zhou, Zhichu (2002). Wan Qing caizheng jingji yanjiu (Research on late Qing fiscal administration), Jinan: Jilu shushe

\section{Notes}

1 These figures are suggestive only; other military expenditures not part of the routine pattern were also made in some years. Official salaries do not indicate the full cost of administration as fees and surtaxes were collected to pay for staff at the local levels and in some cases to enrich officials beyond what was deemed reasonable or considered lawful. 